\title{
Being modern while rejecting modernism, being traditional while dismissing tradition: a brief study of the Portuguese first seven Pousadas (1942-1948)
}

Any field of history is full of themes, more or less defined and/or immutable. In design history continuity and change had been, more often than not, two of these major themes (Heskett 1980: 7; Raizman 2003: 12), commonly understood as leading opposing poles on the design evolution equation and quite summarized on the dichotomy traditionalmodern. Due to almost intrinsic connections between design, industry, technology and, broadly, progress, traditional was repeatedly considered the harmful one.

If in Portugal Design was developed during an autocratic ultra-right regime (1933-1974), it's important to understand how these themes were handled, specially during the first decades when Art assumed a fundamental stand of official moral and socio-politic indoctrination achieved through an assertive propaganda endeavour.

The case study chosen for this dichotomous relation analysis is the construction and decorative programs of the first set of Pousadas established during the 1940's by the regime. Intended as models for the modernization of the national tourism industry, they were also conceived to conform the image of the Portuguese people and nation, as such emerging as a Portuguese home ideal.

Acknowledging perceptible differences in each project, this essay aim is to understand where both themes are discerned: how they converge and induced the general concept and its final results; and how these could be viewed as the result of this regime dual, oxymoronic efforts on modernizing an underdeveloped country and simultaneously keeping it lost in a glorified past.

keywords interior design, Portugal, propaganda, nationalism, identity

\footnotetext{
"Tradition and Progress

When it is said that Estado Novo «stands for the agreement and synthesis of everything that is permanent and everything that is new» - or, in two brief and clear expressions, Tradition and Progress - it is stated one useful and necessary truth, that should be widely known.

This is the moment to merge, in a fertile impulse, these two ideas, that a number of persons, by ignorance or mental retardment, believe incompatible. Tradition and Progress are, after all, complimentary aspects of the same creative force. Links of the same chain. Converging elements of the very same national genius constructive continuity." (Decálogo 1934: 5-7)'
}

${ }^{1}$ The quotations originally in Portuguese are author's free translations. 
In this postulate, presented in the 1934 decalogue published by Estado Novo's [New State $]^{2}$ official propaganda, it's clear the oxymoronic duality of that regime. If on one hand was necessary to affirm the effort to construct a new state supporting the need of a change from a recent decadent past - legacy of modernity, progress and foreign liberal ideas -, on the other hand it was necessary to proclaim perennial national values that should be used as solid foundations of the so called new state. This sense of rupture and construction of a new order over another recent new - common of the fascist regimes and lately viewed, by some factions of the political historiography, as one more possible variant of modernism ${ }^{3}$ - is central to understand this modern/traditional conflict.

\section{The regime, its propaganda and tourism}

In Estado Novo Salazar included different factions of Portuguese ultra-right in order to achieve the necessary equilibrium of forces - congregating from reactionaries to authoritarian moderns, all against one unique enemy, the social-liberal-democratic system (Rosas 1989) - establishing this regime not only as a rupture from the recent past, but as a blend absorbing antagonist groups, a situation especially felt during the first years.

Considered fascist in the broadest sense, Estado Novo initially tried to differentiate itself from other analogous regimes as this original [hybrid] state that struggle to somehow grasp the contemporaneity, simultaneously making an effort to keep the country locked in a gone-by glorified, bucolic and pious dream. Salazar incarnated a stoic persona that carried out the divine duty of fathering the country, giving up his personal freedom for the Nation (Rivero 2010).

To maintain this unquestionable power, Estado Novo promoted nationalistic values based on a permanent celebration of the country's historic global mission and ethnicaluniqueness, as common in authoritarian regimes (Acciaiuoli 1991). The most effective method for this identity implementation was a previous widespread indoctrination of their own established truths irrefutably prevailing and suppressing others opposing truths through an effective propagandistic agenda.

The SPN/SN/4 creation in 1933 answered this need, as propaganda services were now

\footnotetext{
2 The 1926 coup d'état was the outcome of an extended crisis led by the stabilization failure of the liberal-democratic systems experienced since one century before. After an unstable beginning, the regime found its pace under António Salazar (1889-1970) authority, a conservative economy professor, invited in 1928 to straighten out the national debt as an all-powerful Finance Minister; he gradually secured more prominent governmental roles until arising as Prime Minister in 1932, circumstance strengthened with the 1933 Constitution, establishing the power on a single party corporative regime Estado Novo - that held Salazar as a de facto dictator.

3 "MODERNISM: [...] Beyond the sphere of aesthetics and «high» culture, the palingenetic dynamics of modernism have also shaped numerous personal projects and collective movements to establish a healthier social and ethical basis for society, or inaugurate an entirely new socio-political order. This order is conceived as an alternative modernity which holds out the prospect of putting an end to political, cultural, moral, and/or physical dissolution, and sometimes looks forward to the emergence of a new type of «man»." (Griffin 2007: 54-55)

${ }^{4}$ SPN-Secretariado de Propaganda Nacional [National Propaganda Bureau]. In 1944 was renamed SNI-Secretariado Nacional de Informação, Cultura Popular e Turismo [National Bureau of Information, Popular Culture and Tourism].
} 
inevitable tools for governments, mandatory in authoritarian regimes. While refusing the idea of modernity, ironically it would be through these modern instruments that the regime would publicize its ideology as "Propaganda emerged as a fundamental strategy of the society acceptance of itself, and presented as revelation of its own «core»" (Melo 2001: 54).

António Ferro (1895-1956) ran SPN/SNI from its formation in 1933 until 1949. A cosmopolitan writer associated with the Portuguese and European modernist and futurist milieu since his youth ${ }^{5}$, he would gather an assorted group of artists $^{6}$, some old companions, others flourishing artists - according to him "two dozen of lads, full of talent and vigour, that wait, anxiously, to be useful to their Country!" (Ferro 1933: 89) - to help him implement Política do Espirito [Policy of the Spirit], his aesthetic and cultural program formulated just before his political ascension,

"The Art and Literature conscious and deliberated development is, after all, as needed to a nation progress as its sciences, public infrastructures, industry, commerce and agriculture development." (Ferro 1932).

In 1940, seven years after the development of diverse successful activities7, SPN/SNI would willingly assimilate in its duties the tourism task:

"long time we dreamed, almost childish, with that crayon box, with that excuse to raise up our taste level, to beautify the nation, to accentuate its poetry and elegance, to try to, in this new assignment, to clean it up." (Ferro 1949: 10)

\section{An occasional home that could be our own ${ }^{8}$}

One of the first projects would be to conclude the recent decision to build small guesthouses, Pousadas ${ }^{9}$, scattered in key locations throughout the country covering the feeble and obsolete - or simply inexistent — private offer on accommodation and meals (Fig.1). Initially conceived (1938) by the Public Works Ministry, in 1940 the Pousadas were in full construction despite failing almost completely in its comfort and functional requirements

\footnotetext{
${ }^{5}$ With 19 years old (1915) he edited Orpheu, the avant-garde magazine that laid the Portuguese modernist movement foundations with Pessoa, Sá-Carneiro and Almada, among others. While working as journalists Ferro wrote novels, poems and plays (some creating public outrage). As reporter he interviewed d'Annunzio, Maurras, Pétain, Rivera, Mussolini, even Hitler, but also Cocteau, Mistinguett or Poiret. Politically he began as a Republican Party sympathizer, evolving to the authoritarian modern Sidonists and the Conservative Republicans, while progressively admiring contemporary authoritarian regimes, especially Mussolini's. In 1932, when interviewing Salazar, the political role of culture was discussed; months later Salazar invited him to create SPN.

${ }^{6}$ Among the team of artistas-decoradores [decorator-artists] were Bernardo Marques, Carlos Botelho, Eduardo Anahory, Emmérico Nunes, Estrela Faria, José Rocha, Manuel Lapa, Maria Keil, Fred Kradolfer, the Novais brothers, Paulo Ferreira, and Tom.

${ }_{7}$ Several popular competitions; creation of theatre and ballet companies; traveling cinema and libraries services; diverse multilingual editorial lines (from guides and catalogues to propaganda pamphlets); extensive program of prizes; development of an ethnographic collection internationally presented; production of a large number of exhibitions; and the significant task of presenting Portugal abroad in many different events.

8 "the occasional home that belongs to everyone but could be our own..." (Ferro, 1949: 53).

9 Inaugurated between 1942 and 1948.
} 
theme 2

memory

Figure 1.

Marão, Vouga and Alportel pousadas (images: Fundação António Quadros archives) strand 1

design histories: tradition, transgression and transformations

due to errors that would undermine the initial purpose ${ }^{10}$, consequence of being originally misconceived just as "big stomachs to the travellers" (Azevedo 1962: 225-226).

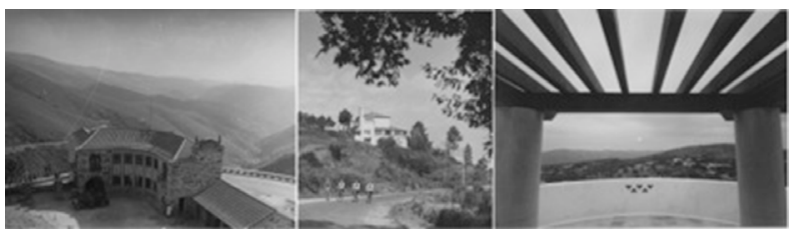

Upon being responsible for them, SPN/SNI services tried to improve on presentday comfort demands, while simultaneously developed the decorative schemes that encapsulate its program main intent:

"Therefore, we tried that these small hotels didn't look like hotels. If the guest entering a Pousada has the impression that he didn't enter a tourism establishment [...] but his own home [...] we achieved our goals" (Ferro 1949: 68-69)

Buildings, gastronomy, garments and decorative elements, everything should be unique, diverse, and rooted on local traditions driving the guests away from the common monotonous standardization of cosmopolitan touristic premises, identical everywhere else in the world.

"War to fake and pretentious «Palaces»! Apart from big cities, what we need, what our landscape needs, are simple guest houses, simple inns, very clean, very bright, comfortable but not luxurious, built and fitted to each region taste, a simple inflorescence of the local life and costumes. [...] Portugal is a tourism country, but this healthy and bucolic tourism should fulfil the traveller needs without loosing our Nation lyric and familiar character." (Ferro 1949: 48)

The first expedient to guarantee this desired organic diversity was to choose different authors for the projects: Brandão Carvalho at Serra do Marão; Maria Keil, Serra da Estrela; Carlos Botelho, Serém- Vale do Vouga; Veloso Camelo, Alfeizeirão- S. Martinho do Porto; and only the three southernmost (Elvas, Santiago do Cacém and S. Braz de Alportel) were decorated by the same team Vera Leroi-Anne Marie Jauss ${ }^{11}$.

Reinforcing this organic intent of mimetically create a home, some designers (Carvalho and Leroi-Jauss) conceived specific furniture for each bedroom masterly proliferating shapes, colours, details, etc., while others (Keil and Botelho) opt to create a more congruent family of objects where forms, materials and decorative features unified the different spaces and functions nevertheless diversifying it with artefacts, textiles or art.

\footnotetext{
$1^{10}$ Erroneously sized for the demand; forgotten servants' accommodations; disconnected from electricity, water and sewage networks; no central heating and malfunctioning boilers made the services quality obviously suffer. Even the edification, due to an extreme parsimonious attitude, would need constant fixings and improvements.

"The same measure was previously used for the architects' choice: mountain buildings done by Rogério Azevedo, littoral ones by Veloso Camelo, the southermost by Jacobetty Rosa.
} 


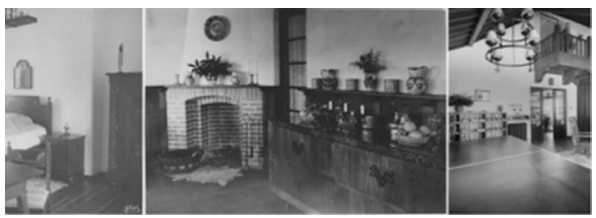

Searching for something new and authentic that could create a fracture with the Portuguese tendency to follow foreign influences - decadent decorative styles or unjustified recent modernisms -, they immerse themselves in recent SPN/SNI sponsored ethnographic studies abiding, in fact, by the avant-garde interest in the primitive and vernacular arts, considered the remaining innocent and decontaminated western world art expression.

To achieve this unique quality the designers grounded the diverse decorative schemes on the local character: picking materials, techniques, ornamental details - more or less regarding its veracity - and adapting them to contemporary life as it was impossible to achieve the necessary comfort level with the original modest pieces found on the rural vernacular interiors (Fig.2). About his proposal to Marão, Brandão Carvalho would say

"Almost all the decorative motifs were searched on the Marão people's art, but everything was adapted to the comfort requirements as the roughness of the furniture and utensils of those mountain persons is a sign of a simple and primitive life, stripped of all well-being. The furniture is nevertheless enhanced by some naif carvings and the ironwork candid contours.

Cloths are sombre, because the fabrics weaved on these highlander's looms are not merry and gay as natural tone wool, without fancy colourings, is motive enough for their decorative efforts.

Iron made lamps and candlesticks are adapted the best way to electric light, since electricity is a recent invention it didn't give people opportunity to create for it appliances with artistic and popular appearance" (Carvalho 1941).

Marão Pousada resulted in an almost monolithic granite exterior, grasping the mountain curve, and very sparse interiors - characteristic best achieved in the bedrooms. Furniture and cloths were minimalistic austere, with small rough incisions or embroidered patterns, more due to an interpretation of traditional production methods than modernity. Conversely, in the south, the Pousadas were brighter and merrier, evidencing the joyful local people. Colourful ceramics, textiles and artefacts embellished luminous white spaces where some furniture accused more recent references (Fig. 3).
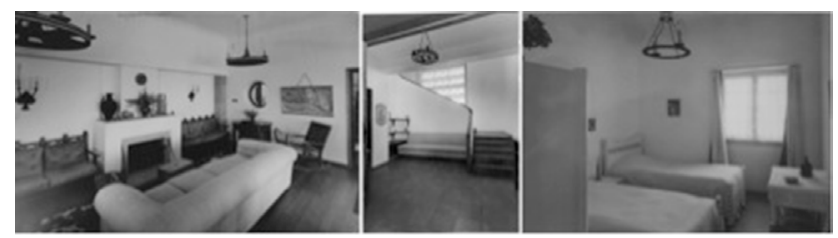

Figure 3. Southern interiors: Alportel, Santiago and Elvas

More respectful (Carvalho, Keil) or more abstract (Botelho, Leroi-Jauss), the results denoted this popular arts' modern reinterpretation pursuing a newborn visual expression that should support the dual regime's desired nationalistic values of Progress and Tradition. 


\section{Conclusion}

The conflicting points of view on this paper's title are revealed in these home projects, testifying Estado Novo first decades of ambiguous actions. It should be mentioned the work of a generation that, after thriving through the 1920's modernism, latterly yearned to raise a new modernized country proud of its primeval roots and free from the heavy burden of historically institutional tradition - something revolutionary in a peripheral country with self-esteem problems, ashamed of itself except from some history episodes. At the same time it's recognizable their efforts to shift from the international stylistic hegemony - the enduring eclectic styles or the recent modernism - nevertheless using the later analysis and synthesis methods to translate the vernacular to this recreated tradition. This new methodological conscience and practice is unquestionably of great importance - it came on to shape the Portuguese design foundation stones, born years later.

\section{References}

Acciaiuoli, M. (1991). [PhD thesis] Os anos 40 em Portugal. Lisboa: FCSH-UNL Azevedo, R. (1962). [Letter]. 1962-10-30. Dando cumprimento ao... [Manuscript]. Acessible at IHRU/SIPA, Lisboa. PT-DGEMN archiv, DSARH-011/026-0162/03, pp. 223-226.

Carvalho, J.L.B. (1941). [Report]. 1941-08. A exigüidade da verba... [Manuscript]. Acessible at IAN/TT, Lisboa. SNI archiv, CX-1103, PT-TT-SNI/DGT/I/1/1.

Decálogo do Estado Novo (1934). Lisboa: SPN.

Ferro, A. (1932). Política do Espírito. Diário de Notícias. Lisboa. (21 Nov 1932). p. 1 (1933). Salazar. Lisboa: ENP. (1949). Turismo. Lisboa: SNI.

Griffin, R. (2007). Modernism and Fascism. Hampshire: Palgrave Macmillan. Heskett, J. (980). Industrial Design. London Thames and Hudson Melo, D. (2001). Salazarismo e Cultura Popular (1933-1958). Lisboa: ICS. Raizman, D. (2003). History of Modern Design. London: Laurence King Rivero, Á. (2010). Salazar and Charismatic Leadership [Electronic]. Acessible at WWW: '<url:http://www.lse.ac.uk/researchAndExpertise/units/ASEN/Conference/ PastConferences/2010/conferencepapers2010/Angel_Rivero.pdf' [20 Mar 2012] Rosas, F. (1989). A crise do Liberalismo e [...]. Penélope, Fazer e Desfazer a História. no. 2, Feb. 1989, pp.98-114. 